\title{
TEAMS GAMES TOURNAMENT DENGAN PERMAINAN LUDO AKUNTANSI UNTUK MENINGKATKAN AKTIVITAS BELAJAR AKUNTANSI
}

\section{TEAMS GAMES TOURNAMENT WITH ACCOUNTING LUDO GAME TO IMPROVE ACCOUNTING LEARNING ACTIVITY}

\author{
Oleh: \\ Susan Mardiana
}

Prodi Pendidikan Akuntansi Universitas Negeri Yogyakarta susanmardiana1111@gmail.com

Moh. Djazari

Staf Pengajar Jurusan P. Akuntansi Universitas Negeri Yogyakarta

\begin{abstract}
Abstrak
Penelitian Tindakan Kelas ini bertujuan untuk meningkatkan Aktivitas Belajar Akuntansi Siswa Kelas X AK 2 SMK Negeri 1 Godean Tahun Pelajaran 2014/2015 melalui penerapan Metode Pembelajaran Kooperatif Tipe Teams Games Tournament (TGT) dengan Permainan Ludo Akuntansi. Metode pengumpulan data yang digunakan dalam penelitian ini adalah observasi partisipatif/ pengamatan, angket, dokumentasi, dan catatan lapangan. Analisis data yang digunakan adalah analisis data deskriptif kuantitatif dengan persentase. Berdasarkan hasil penelitian, disimpulkan bahwa Penerapan Metode Pembelajaran Kooperatif Tipe Teams Games Tournament (TGT) dengan Permainan Ludo Akuntansi dapat Meningkatkan Aktivitas Belajar Akuntansi Siswa Kelas X AK 2 SMK Negeri 1 Godean Tahun Pelajaran 2014/2015. Hal ini dibuktikan dengan adanya peningkatan di setiap indikator Aktivitas Belajar Akuntansi dari siklus I ke siklus II. Peningkatan persentase rata-rata Aktivitas Belajar Akuntansi sebesar 19,29\%, berasal dari persentase rata-rata Aktivitas Belajar Akuntansi dari siklus I $69,35 \%$ menjadi $88,64 \%$ pada siklus II.
\end{abstract}

Kata kunci: Metode Pembelajaran Kooperatif Tipe Teams Games Tournament (TGT), Permainan Ludo Akuntansi, Aktivitas Belajar Akuntansi

\begin{abstract}
This Classroom Action Research aimed to improve Accounting Learning Activity Class Student of X AK 2 SMK Negeri 1 Godean Academic Year 2014/2015 throught the implementation of Cooperative Learning Method Type Teams Games Tournament (TGT) with Accounting Ludo Game. The method of collecting data used in this research are participative observation, questionnaire, documentation, and field note. Method of analizing data used in this research is quantitative analysis descriptive data with percentage. Based on the research result, it is concluded that The Implementation of Cooperative Learning Methode Type Teams Games Tournament (TGT) with Accounting Ludo Game could improve Accounting Learning Activity Class Student of X AK 2 SMK Negeri 1 Godean Academic Year 2014/2015. This matter is proven by there were increasing in every indicators of Accounting Learning Activity from first cycle to second cycle. The increasing average percentage of Accounting Learning Activity in the amount of 19,29\%, originated from average percentage of Accounting Learning Activity in first cycle 69,35\% became $88,64 \%$ in second cycle.
\end{abstract}

Keywords: Cooperative Learning Method Type Teams Games Tournament (TGT), Accounting Ludo Game, Accounting Learning Activity 


\section{PENDAHULUAN}

Aktivitas Belajar Akuntansi adalah serangkaian kegiatan yang akan menimbulkan perubahan tingkah laku siswa selama mengikuti pembelajaran akuntansi. Aktivitas Belajar Akuntansi terdiri dari beberapa jenis, diantaranya adalah aktivitas mendengarkan, visual, menulis, bertanya, dan mengungkapkan pendapat yang berhubungan dengan pembelajaran akuntansi. Dalam pembelajaran akuntansi tentu Aktivitas Belajar Akuntansi sangat diperlukan untuk menunjang terciptanya pembelajaran akuntansi yang aktif di dalam kelas. Hal ini dapat terlihat dari banyaknya siswa yang ikut berpartisipasi aktif dalam pembelajaran akuntansi. Agar tercipta Aktivitas Belajar Akuntansi maka guru harus mampu menempatkan siswa sebagai subjek belajar dan bukan objek belajar serta dapat memilih metode pembelajaran yang tepat. Dengan menempatkan siswa sebagai subjek belajar maka siswa dapat turut serta aktif dalam proses pembelajaran dan tidak terlalu bergantung hanya pada guru.

Berdasarkan observasi pada tanggal 26 November 2014 di kelas X AK 2 SMK Negeri 1 Godean terdapat beberapa permasalahan yang berhubungan dengan Aktivitas Belajar Akuntansi. Permasalahanpermasalahan tersebut diantaranya adalah masih terdapat siswa yang belum aktif. Dari 32 siswa hanya ada $10(31,25 \%)$ siswa yang aktif menjawab dan bertanya kepada guru, sisanya ada yang berbicara dengan temannya dan ada yang melamun. Selain itu sebanyak $16(50 \%)$ siswa tidak mencatat materi yang dijelaskan guru. Penggunaan metode pembelajaran ceramah dan guru yang hanya fokus ada di depan kelas juga mengakibatkan menurunnya Aktivitas Belajar Akuntansi. Pembelajaran akuntansi dapat dikatakan aktif jika lebih dari $75 \%$ siswa ikut aktif dalam proses pembelajaran akuntansi (E. Mulyasa, 2006: 256). Dari permasalahan-permasalahan di atas maka dapat dikatakan bahwa pembelajaran akuntansi di kelas X AK 2 SMK Negeri 1 Godean belum termasuk aktif. Permasalahan lain yaitu siswa diharuskan untuk memahami dengan baik materi Jurnal Umum dan Buku Besar karena merupakan materi awal yang menjadi dasar agar dapat menyelesaikan soal-soal akuntansi yang diberikan oleh guru. Jika salah dalam memahami materi Jurnal Umum dan Buku Besar maka siswa ke depannya akan kesulitan untuk memahami materi selanjutnya. Oleh karena itu diperlukan metode pembelajaran yang tepat agar materi Jurnal Umum dan Buku Besar dapat dipahami dengan baik dan benar.

Berdasarkan permasalahan-permasalahan di atas maka diperlukan solusi yang tepat agar siswa dapat terlibat aktif dalam pembelajaran akuntansi sehingga dapat meningkatkan Aktivitas Belajar Akuntansi siswa. Solusi untuk permasalahan di atas adalah dengan penerapan Metode Pembelajaran Kooperatif Tipe Teams Games Tournament (TGT) dengan Permainan Ludo Akuntasi. Menurut Slavin (2014: 166-167) Teams Games Tournament (TGT) merupakan metode pembelajaran kooperatif dengan langkah kerja presentasi di kelas, pembentukan kelompok, memainkan permainan serta melaksanakan turnamen, dan rekognisi kelompok.

Metode Pembelajaran Kooperatif Tipe Teams Games Tournament (TGT) dengan Permainan Ludo Akuntasi dipilih karena dalam metode ini seluruh siswa terlibat aktif dalam proses pembelajaran akuntansi dan penambahan Permainan Ludo Akuntansi akan menarik minat siswa untuk berpartisipasi aktif dalam proses pembelajaran akuntansi. Guru membentuk kelompok berdasarkan kemampuan akademik yang heterogen dalam metode pembelajaran kooperatif ini, selanjutnya siswa belajar bersama dalam kelompok untuk menyelesaikan lembar kerja dari guru. Hal ini dapat meningkatkan Aktivitas Belajar Akuntansi karena setiap siswa akan saling membantu dalam mempersiapkan diri untuk memainkan Permainan Ludo Akuntansi dalam turnamen. Permainan Ludo Akuntansi adalah permainan Ludo yang 
telah dimodifikasi dengan memasukkan unsur pelajaran akuntansi ke dalam permainan ini. Dalam turnamen setiap siswa akan memainkan Ludo Akuntansi. Cara memainkan Ludo Akuntansi adalah dengan menggerakkan pion untuk secepat mungkin mencapai home dengan cara menjawab pertanyaan-pertanyaan yang telah disediakan. Siswa akan berusaha untuk menjadi yang tercepat dan terbaik agar mendapatkan poin bagi kelompok mereka, hal ini juga akan meningkatkan Aktivitas Belajar Akuntansi.

Berdasarkan penjelasan di atas peneliti tertarik untuk melakukan Penelitian Tindakan Kelas dengan judul "Penerapan Metode Pembelajaran Kooperatif Tipe Teams Games Tournament (TGT) dengan Permainan Ludo Akuntansi untuk Meningkatkan Aktivitas Belajar Akuntansi Siswa Kelas X AK 2 SMK Negeri 1 Godean Tahun Pelajaran 2014/2015".

Tujuan dari penelitian ini yaitu untuk mengetahui peningkatan Aktivitas Belajar Akuntansi pada Siswa Kelas X AK 2 SMK Negeri 1 Godean Tahun Pelajaran 2014/2015 dengan Penerapan Metode Pembelajaran Kooperatif Tipe Teams Games Tournament (TGT) dengan Permainan Ludo Akuntansi.

Hasil yang diperoleh dari penelitian ini diharapkan memiliki kegunaan bagi berbagai pihak. Bagi siswa agar dapat meningkatkan Aktivitas Belajar Akuntansi dengan menggunakan Metode Pembelajaran Kooperatif Tipe Teams Games Tournament (TGT) dengan Permainan Ludo Akuntansi. Bagi peneliti yaitu agar memiliki pengetahuan, keterampilan, dan pengalaman tentang Penelitian Tindakan Kelas. Bagi guru yaitu sebagai masukan bagi guru SMK dalam mengajarkan akuntansi.

Variabel dalam penelitian ini ada dua yaitu Aktivitas Belajar Akuntansi dan Metode Pembelajaran Kooperatif Tipe Teams Games Tournament (TGT) dengan Permainan Ludo Akuntansi. Aktivitas Belajar Akuntansi adalah kegiatan yang bersifat fisik dan mental yang dilakukan secara sadar oleh individu untuk memperoleh perubahan tingkah laku yang pada akhirnya dapat menunjang keberhasilan belajar akuntansi. Selain itu, dapat pula diartikan sebagai suatu kegiatan yang sengaja dirancang guru agar siswa dapat berperan aktif dalam proses pembelajaran akuntansi. Metode Pembelajaran Kooperatif Tipe Teams Games Tournament (TGT) dengan Permainan Ludo Akuntansi adalah salah satu metode pembelajaran kooperatif yang melibatkan aktivitas seluruh siswa dan mengandung unsur Permainan Ludo Akuntansi yang dapat saling menguatkan sesama anggota kelompok.

\section{METODE PENELITIAN}

\section{Jenis Penelitian}

Penelitian ini merupakan Penelitian Tindakan Kelas yang berfokus untuk meningkatkan Aktivitas Belajar Akuntansi Siswa SMK Negeri 1 Godean Tahun Pelajaran 2014/2015 dengan menerapkan Metode Pembelajaran Kooperatif tipe Teams Games Tournament (TGT) dengan Permainan Ludo Akuntansi.

\section{Waktu dan Tempat Penelitian}

Waktu penelitian dibagi atas beberapa tahapan yaitu tahap persiapan dimulai pada bulan November 2014, kemudian tahap pelaksanaan penelitian dan pelaporan yaitu pada bulan Januari sampai dengan bulan Maret 2015. Penelitian ini dilaksanakan di kelas X AK 2 SMK Negeri 1 Godean yang berjumlah 32 siswa, yang beralamat di Kowanan, Sidoagung, Godean, Sleman, Yogyakarta, 55564 Telp./Fax. (0274) 978274.

\section{Target/Subjek Penelitian}

Subjek penelitian ini adalah seluruh siswa kelas X AK 2 SMK Negeri 1 Godean tahun pelajaran 2014/2015 yang berjumlah 32 siswa.

\section{Prosedur}

Dalam penelitian tindakan kelas terdapat empat komponen pokok, yaitu 
perencanaan (planning), tindakan (acting), pengamatan (observing), dan refleksi (reflecting). Berikut ini terdapat penjelasan keempat komponen penelitian tindakan kelas yang dilakukan.

a. Siklus I

1) Perencanaan Tindakan

a) Membuat Rencana Pelaksanaan Pembelajaran (RPP) yang menggunakan Metode Pembelajaran Kooperatif Tipe Teams Games Tournament (TGT) dengan Permainan Ludo Akuntansi. RPP ini akan digunakan sebagai pedoman pelaksanaan pembelajaran. Dalam pembuatan RPP ini peneliti terlebih dahulu mengkonsultasikannya dengan guru mata pelajaran akuntansi.

b) Membuat Permainan Ludo Akuntansi

c) Membuat kartu soal bernomor yang berisi tentang pertanyaan yang akan dipakai dalam turnamen.

d) Membagi siswa menjadi 8 kelompok heterogen dengan anggota 4 siswa tiap kelompok orang berdasarkan nilai ujian akhir semester gasal.

e) Menyusun lembar observasi Aktivitas Belajar Akuntansi siswa.

f) Membuat format catatan lapangan yang digunakan untuk mencatat peristiwa-peristiwa penting dalam pembelajaran menggunakan Metode Pembelajaran Kooperatif Tipe Teams Games Tournament (TGT) dengan Permainan Ludo Akuntansi.

g) Membuat angket Aktivitas Belajar Akuntansi

h) Berkonsultasi dengan guru mata pelajaran akuntansi mengenai segala kegiatan pembelajaran yang akan dilakukan.

2) Pelaksanaan Tindakan

Dalam pelaksanaan tindakan peneliti dan rekan sejawat menjadi observer, sedangkan untuk proses pembelajaran akan dilaksanakan oleh guru dengan RPP yang telah dibuat.

3) Pengamatan Tindakan

Pengamatan tindakan dalam penelitian ini dilakukan menggunakan lembar observasi dan catatan lapangan yang telah dibuat sebelumnya. Pengamatan tindakan ini akan fokus dalam mengamati Aktivitas Belajar Akuntansi siswa dengan dibantu rekan sejawat dalam pengamatannya.

4) Refleksi Tindakan

Dalam refleksi tindakan akan didapatkan hasil dari langkah-langkah yang telah dilakukan sebelumnya yang ada pada lembar observasi dan catatan lapangan. Dari hasil-hasil tersebut dapat diketahui masalah-masalah yang ada, setelah itu dilakukan evaluasi terhadap masalah-masalah tersebut dengan bantuan guru mata pelajaran akuntansi. Setelah dilakukan evaluasi peneliti dapat menyusun rencanarencana perbaikan pada siklus II agar tercapai hasil yang optimal.

b. Siklus II

1) Perencanaan Tindakan

Perencanaan tindakan pada siklus II hampir sama dengan siklus I, hanya saja dilakukan perbaikan sesuai dengan refleksi tindakan yang telah dilakukan.

2) Pelaksanaan Tindakan

Pelaksanaan tindakan pada siklus II sama dengan siklus I. Guru mengajar dengan menggunakan Rencana Pelaksanaan Pembelajaran (RPP) pada materi yang merupakan kelanjutan dari siklus I.

3) Pengamatan Tindakan

Pengamatan tindakan pada siklus II sama dengan pengamatan tindakan pada siklus I.

4) Refleksi Tindakan

Refleksi tindakan pada siklus II dilakukan untuk mengetahui perbedaan hasil siklus I dan siklus II. Apakah terjadi peningkatan hasil dari siklus I ke siklus II, jika belum 
terdapat peningkatan maka siklus dapat diulangi lagi.

\section{Data, Intrumen, dan Teknik Pengum- pulan \\ a. Data}

Data diperoleh melalui Observasi Partisipatif/ Pengamatan, Angket, Dokumentasi, dan Catatan Lapangan. Kegiatan observasi ini dilakukan untuk mengamati Aktivitas Belajar Akuntansi siswa pada saat pelaksanaan Metode Pembelajaran Kooperatif Tipe Teams Games Tournament (TGT) dengan Permainan Ludo Akuntansi. Aktivitas Belajar Akuntansi ini dicatat pada lembar observasi untuk setiap siklus. Kegiatan pengamatan akan dilakukan peneliti dan rekan sejawat yang berperan sebagai observer saat pelaksanaan proses pembelajaran. Terdapat sembilan indikator Aktivitas Belajar Akuntansi yang akan diamati.

Dalam penelitian ini, dokumen yang digunakan adalah foto-foto dari proses pembelajaran akuntansi yang menerapkan Metode Pembelajaran Kooperatif Tipe Teams Games Tournament (TGT) dengan Permainan Ludo Akuntansi. Angket dalam penelitian ini adalah angket tentang Aktivitas Belajar Akuntansi. Angket ini berbentuk angket tertutup dan siswa hanya tinggal memberikan tanda check list yang sesuai dengan pilihan mereka.

Catatan Lapangan berfungsi untuk mencatat berbagai hasil pengamatan tentang aspek pembelajaran di kelas, suasana kelas, pengelolaan kelas, interaksi guru dengan siswa, interaksi siswa dengan siswa dan beberapa aspek dan akan digunakan sebagai sumber data penelitian tindakan kelas. Catatan lapangan juga digunakan untuk membantu dalam proses refleksi.

\section{b. Teknik Analisis Data}

Teknik analisis data yang digunakan dalam penelitian ini adalah analisis data deskriptif kuantitatif dengan persentase. Analisis data deskriptif kuantitatif dengan persentase digunakan untuk menganalisis data observasi Aktivitas Belajar Akuntansi dan data angket.

1) Analisis Data Observasi Aktivitas Belajar Akuntansi (ABA)

a) Mengolah skor Aktivitas Belajar Akuntansi

(1) Membuat indikator penskoran untuk Aktivitas Belajar Akuntansi.

(2) Menghitung dan menjumlahkan skor Aktivitas Belajar Akuntansi siswa untuk setiap indikator.

(3) Menghitung persentase Aktivitas Belajar Akuntansi pada setiap indikator yang diamati dengan rumus berikut:

$\%=\underline{\text { Skor tiap ABA siswa }} \times 100 \%$

Skor Maksimum

(Sugiyono, 2012: 137)

b) Menghitung persentase rata-rata Aktivitas Belajar Akuntansi dengan cara membagi persentase total Aktivitas Belajar Akuntansi dengan jumlah indikator yang digunakan.

c) Menyajikan data

Setelah data Aktivitas Belajar Akuntansi diolah, data ditampilkan secara sederhana dan disajikan ke dalam bentuk tabel dan grafik.

d) Menarik kesimpulan

Penarikan kesimpulan dilakukan untuk menjawab rumusan masalah yang diajukan pada awal penelitian. Dalam penelitian ini, setelah data disajikan dalam bentuk tabel dan grafik, dilakukan pemaknaan data ke dalam pernyataan.

2) Analisis Angket Aktivitas Belajar Akuntansi

Hasil angket Aktivitas Belajar Akuntansi dianalisis dengan menggunakan persentase hasil dari keseluruhan jawaban. Persentase hasil angket dapat dihitung dengan rumus yang sama saat menghitung persentase data observasi Aktivitas Belajar Akuntansi. 


\section{HASIL PENELITIAN DAN PEMBA- HASAN}

Penelitian ini dilakukan dalam dua siklus. Metode Pembelajaran Kooperatif Tipe Teams Games Tournament (TGT) dengan Permainan Ludo Akuntansi diterapkan pada Materi Jurnal Umum dan Buku Besar. Pelaksanaan dua siklus bersifat fleksibel, yaitu apabila setelah siklus II Aktivitas Belajar Akuntansi siswa sudah mencapai kriteria keberhasilan minimal $(>75 \%)$, maka penelitian dapat diakhiri, namun apabila setelah siklus II Aktivitas Belajar Akuntansi siswa belum mencapai kriteria indikator keberhasilan minimal, maka penelitian dapat dilanjutkan ke siklus III sampai mencapai kriteria keberhasilan minimal.

Setiap siklus terdiri dari dua kali pertemuan sehingga akan ada empat kali pertemuan dalam Penelitian Tindakan Kelas ini. Pertemuan pertama siklus I dilaksanakan pada tanggal 20 Januari 2015 dan pertemuan kedua siklus I dilaksanakan pada tanggal 27 Januari 2015. Pertemuan pertama siklus I dilaksanakan pada tanggal 28 Januari 2015 dan pertemuan kedua siklus II dilaksanakan pada tanggal 2 Februari 2015. Penelitian ini menerapkan Metode Pembelajaran Kooperatif Tipe Teams Games Tournament (TGT) dengan Permainan Ludo Akuntansi. Materi yang dipelajari di siklus I adalah Jurnal Umum dan di siklus II adalah Buku Besar.

Pada pertemuan pertama di siklus I dilaksanakan presentasi kelas dan belajar kelompok dengan mempelajari materi Jurnal Umum. Setelah guru mempresentasikan materi mengenai Jurnal Umum maka dilanjutkan dengan belajar kelompok. Dalam belajar kelompok siswa akan dikelompokkan dalam delapan kelompok heterogen. Heterogen dalam hal ini adalah heterogen kemampuan akademiknya, jadi pada setiap kelompok akan ada siswa dengan kemampuan akademik tinggi, sedang, dan rendah. Kelompok ini dibuat berdasarkan nilai Ujian Akhir Semester semester I mata pelajaran Pengantar Akuntansi dan Keuangan. Pada saat presentasi di kelas siswa memperhatikan materi yang dijelaskan guru agar dapat menjadi bekal ketika akan mengerjakan soal saat belajar kelompok. Pada saat belajar kelompok siswa yang sudah dikelompokkan dengan kemampuan akademik yang heterogen saling bekerjasama untuk menyelesaikan soal belajar kelompok. Setiap siswa saling membantu agar dapat menyelesaikan soalsoal yang diberikan dan pada akhirnya akan menjadi bekal bagi siswa untuk memecahkan soal pada saat turnamen.

Setelah dilaksanakan belajar kelompok maka dilaksanakan turnamen dengan Permainan Ludo Akuntansi. Dalam turnamen setiap siswa menjadi wakil dari masing-masing kelompok heterogen karena pada turnamen siswa dikelompokkan berdasarkan kelompok yang homogen kemampuan akademiknya. Urutan pelaksanaan turnamen dengan Permainan Ludo Akuntansi adalah sebagai berikut:

1. Siswa berkumpul sesuai dengan kelompok yang telah dibagi.

2. Siswa menyiapkan papan Permainan Ludo Akuntansi, pion, kartu soal, lembar jawaban, dan lembar poin turnamen.

3. Siswa memilih pion, mengocok kartu soal, dan mengundi urutan main dengan hom pim pah.

4. Siswa mengambil kartu soal kemudian memberikan kartu soal kepada siswa dengan urutan berikutnya untuk dibacakan.

5. Siswa menjawab soal yang telah dibacakan di lembar yang telah disediakan.

6. Setiap siswa hanya diberikan waktu maksimal 3 menit untuk menjawab soal.

7. Siswa lain juga diperbolehkan untuk menjawab soal di lembar yang telah disediakan (kecuali pembaca soal).

8. Penjawab soal menyampaikan jawabannya dan mengonfirmasi jawaban kepada pembaca soal. 
9. Pembaca soal melihat kunci jawaban yang telah ditempel di belakang kartu soal.

10. Jika jawaban benar, penjawab soal diperbolehkan melangkah maju di papan Permainan Ludo Akuntansi sesuai dengan angka yang tertulis di sudut kanan atas kartu soal.

11. Jika jawaban benar, penjawab soal mendapat poin 20 dan menulis poinnya dalam lembar poin turnamen (siswa lain ikut mengawasi agar tidak terjadi kecurangan).

12. Jika jawaban salah, penjawab soal tidak mendapatkan poin dan tidak diperbolehkan melangkah maju di papan Permainan Ludo Akuntansi serta soal dapat diperebutkan oleh siswa lain (selain penjawab dan pembaca soal) dengan cara suit.

13. Kartu soal yang telah dijawab wajib disimpan oleh penjawab soal yang benar.

14. Siswa mengulangi permainan hingga kartu soal habis.

15. Jika ada siswa yang pertama kali mencapi home maka akan mendapatkan poin ekstra sebesar 10 poin.

16. Turnamen dengan Permainan Ludo Akuntansi dianggap berakhir jika kartu soal atau waktu yang ditentukan telah habis.

17. Seluruh siswa diminta ke kelompok awal dan melakukan rekapitulasi poin yang didapatkan dari turnamen dengan Permainan Ludo Akuntansi.

Pada turnamen di siklus I rekapitulasi poin tidak dapat terlaksana karena keterbatasan waktu sehingga tidak dapat membagikan reward bagi tiga kelompok dengan poin tertinggi dan pembagian reward akan dilaksanakan pada awal pertemuan pertama siklus I. Secara keseluruhan masih terdapat beberapa kendala dalam pelaksanaan siklus I yaitu:

1. Siswa belum terbiasa menerapkan Metode Pembelajaran Kooperatif Tipe
Teams Games Tournament (TGT) dengan Permainan Ludo Akuntansi

2. Siswa masih merasa kebingungan dengan peraturan saat turnamen menggunakan Permainan Ludo Akuntansi

3. Keterbatasan waktu dalam proses pembelajaran menyebabkan tidak terlaksananya rekapitulasi poin turnamen

Pada siklus I persentase Aktivitas Belajar Akuntansi sebesar 69,35\%. Persentase tersebut masih belum mencapai kriteria keberhasilan minimal sebesar > $75 \%$. Oleh karena itu, maka dilanjutkan pada siklus II untuk guna memperbaiki siklus I. Kendala-kendala yang ada di siklus I perlu diselesaikan agar siklus II berjalan dengan optimal dan Aktivitas Belajar Akuntansi dapat mencapai kriteria keberhasilan minimal. Usaha yang dilakukan untuk perbaikan pada siklus II adalah sebagai berikut:

1. Memberikan petunjuk yang jelas pada siswa hingga siswa benar-benar memahami Metode Pembelajaran Kooperatif Tipe Teams Games Tournament (TGT) dengan Permainan Ludo Akuntansi.

2. Memberikan penjelasan ulang kepada siswa hingga siswa benar-benar memahami peraturan dalam Permainan Ludo Akuntansi.

3. Menggunakan waktu pembelajaran secara efisien agar seluruh rangkaian kegiatan dalam penerapaan Metode Pembelajaran Kooperatif Tipe Teams Games Tournament (TGT) dengan Permainan Ludo Akuntansi berjalan sesuai rencana.

Tahap-tahap yang ada di siklus II sama dengan siklus I yaitu pada pertemuan pertama presentasi di kelas dan belajar kelompok, serta pada pertemuan kedua adalah turnamen dengan Permainan Ludo Akuntansi. Materi yang dipelajari pada siklus II adalah Buku Besar. Pembelajaran dengan penerapan Metode Pembelajaran Kooperatif Tipe Teams Games Tournament 
(TGT) dengan Permainan Ludo Akuntansi pada siklus II sudah mengalami peningkatan, dilihat dari Aktivitas Belajar Akuntansi siswa kelas X AK 2 SMK Negeri 1 Godean pada siklus II dibandingkan dengan siklus I. Pengelolaan kelas terlaksana dengan baik sehingga siswa dapat mengikuti pembelajaran secara optimal pada siklus II. Peningkatan pada siklus II tidak terlepas dari perbaikanperbaikan yang dilakukan sesuai dengan hasil refleksi siklus I. Pada siklus II persentase Aktivitas Belajar Akuntansi sudah mencapai kriteria keberhasilan minimal yaitu sebesar $88,64 \%$.

Berdasarkan lembar observasi yang dilakukan pada setiap siklus selama penerapan Metode Pembelajaran Kooperatif Tipe Teams Games Tournament (TGT) dengan Permainan Ludo Akuntansi maka diketahui persentase Aktivitas Belajar Akuntansi pada siklus I sebesar $69,35 \%$. Pada siklus I belum memenuhi kriteria keberhasilan minimal yaitu $>75 \%$. Oleh karena itu, maka dilanjutkan pada siklus II untuk memperbaiki siklus I. Pada siklus II Aktivitas Belajar Akuntansi sudah mengalami peningkatan sebesar 19,29\% menjadi $88,64 \%$. Jika disajikan dalam bentuk grafik akan tampak sebagai berikut:

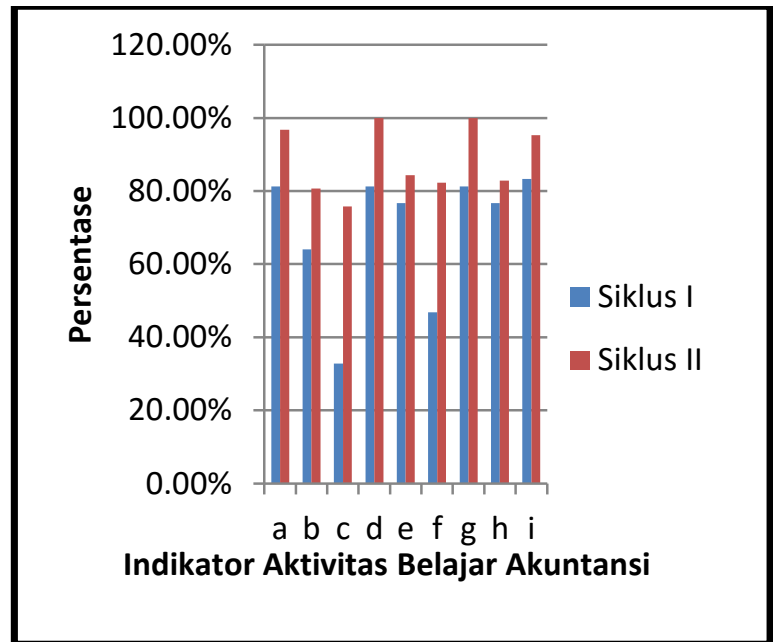

Gambar 1. Grafik Peningkatan setiap Indikator Aktivitas Belajar Akuntansi berdasarkan Obervasi Siklus I dan Siklus II

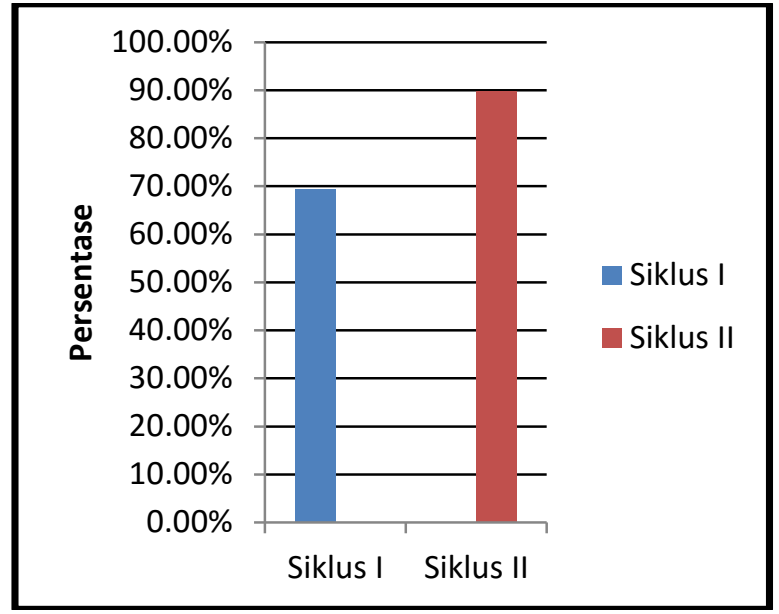

Gambar 2. Grafik Persentase RataRata Aktivitas Belajar Akuntansi berdasarkan Observasi pada Siklus I dan Siklus II

Berdasarkan grafik di atas dikatakan bahwa Aktivitas Belajar Akuntansi mengalami peningkatan dari siklus I ke siklus II. Peningkatan Aktivitas Belajar Akuntansi meliputi kenaikan pada ratarata Aktivitas Belajar Akuntansi secara keseluruhan pada siklus II mencapai kriteria keberhasilan minimal yaitu > $75 \%$.

Pada setiap akhir siklus dilakukan pendistribusian angket Aktivitas Belajar Akuntansi. Angket dibuat berdasarkan 9 indikator yang terdiri dari 20 pernyataan. Angket yang digunakan dalam penelitian ini adalah angket tertutup, yaitu angket yang telah dilengkapi dengan alternatif jawaban yang dapat dipilih oleh responden. Alternatif jawaban diambil dari skala Likert yaitu Sangat Setuju (SS), Setuju (S), Tidak Setuju (TS), dan Sangat Tidak Setuju (STS). Angket didistribusikan pada setiap akhir siklus dan setelah itu data yang didapatkan akan diolah lebih lanjut.

Berdasarkan data yang diperoleh dapat diketahui bahwa terjadi peningkatan persentase Aktivitas Belajar Akuntansi sebesar 8,59\% dari 
$74,77 \%$ di siklus I menjadi $83,36 \%$ pada siklus II.

Berdasarkan hasil penelitian di atas dapat disimpulkan bahwa penerapan Metode Pembelajaran Kooperatif Tipe Teams Games Tournament (TGT) dengan Permainan Ludo Akuntansi dapat meningkatkan Aktivitas Belajar Akuntansi Siswa Kelas X AK 2 SMK Negeri 1 Godean tahun pelajaran 2014/2015 dengan Aktivitas Belajar Akuntansi yang telah mencapai kriteria keberhasilan minimal yaitu $>75 \%$.

\section{SIMPULAN DAN SARAN}

\section{Simpulan}

Berdasarkan Hasil Penelitian dan Pembahasan pada bab IV dapat disimpulkan bahwa penerapan Metode Pembelajaran Kooperatif Tipe Teams Games Tournament (TGT) dengan Permainan Ludo Akuntansi dapat meningkatkan Aktivitas Belajar Akuntansi Siswa Kelas X AK 2 SMK Negeri 1 Godean Tahun Pelajaran 2014/2015 yang dibuktikan dengan adanya peningkatan persentase rata-rata Aktivitas Belajar Akuntansi. Peningkatan persentase rata-rata Aktivitas Belajar Akuntansi yang diambil melalui observasi dengan lembar observasi adalah 19,29\% dari $69,35 \%$ di siklus I menjadi $88,64 \%$ pada siklus II. Peningkatan persentase ratarata Aktivitas Belajar Akuntansi yang diambil melalui angket adalah $8,59 \%$ dari $74,77 \%$ di siklus I menjadi $83,36 \%$ pada siklus II.

\section{Saran}

Berdasarkan kesimpulan di atas terdapat beberapa saran sebagai berikut:

a. Bagi Guru Akuntansi SMK Negeri 1 Godean

Guru dapat mencoba menerapkan Metode Pembelajaran Kooperatif Tipe Teams Games Tournament (TGT) dengan Permainan Ludo Akuntansi yang diharapkan dapat meningkatkan Aktivitas Belajar
Akuntansi. Guru perlu merancang pembelajaran yang lebih bervariatif agar siswa bersemangat dalam mengikuti pembelajaran akuntansi di sekolah.

b. Bagi Peneliti Selanjutnya

Penelitian selanjutnya dapat mencoba untuk mengembangkan penelitian tidakan kelas, salah satunya dengan menerapkan Metode Pembelajaran Kooperatif Tipe Teams Games Tournament (TGT) dengan Permainan Ludo Akuntansi untuk meningkatkan Aktivitas Belajar Akuntansi siswa pada pembelajaran Akuntansi dan tentunya pada materi pokok lainnya sehingga dapat memperkaya khasanah ilmu pengetahuan di bidang pendidikan.

\section{DAFTAR PUSTAKA}

Al Haryono Jusup. (2011). Dasar-dasar Akuntansi. Yogyakarta: Bagian Penerbitan Sekolah Tinggi Ilmu Ekonomi YKPN.

Amin Sholikhah. (2013). "Implementasi Metode Pembelajaran Kooperatif Teknik Team Games Tournament (TGT) dengan Bantuan Media Ular Tangga Untuk Meningkatkan Aktivitas Belajar Akuntansi Siswa Kelas XI IPS 3 SMA Negeri 1 Imogiri Tahun Ajaran 2013/2014". Skripsi. Universitas Negeri Yogyakarta.

Arief S. Sadiman, dkk. (2011). Media Pendidikan: Pengertian, Pengembangan, dan Pemanfaatannya. Jakarta: PT. Rajagrafindo Persada.

Daryanto dan Mulyo Rahardjo. (2012). Model Pemelajaran Inovatif. Yogyakarta: Penerbit Gava Media. 
E. Mulyasa. (2006). Kurikulum Tingkat Satuan Pendidikan Sebuah Panduan Praktis. Bandung: PT. Remaja Rosdakarya.

Hendi Somantri. (2007). Memahami Akuntansi untuk SMK Seri A. Bandung: CV Armico.

Hery. (2011). Akuntansi Perusahaan Jasa dan Dagang. Bandung: Penerbit Alfabeta.

Ika Nursanti. (2014). "Penerapan Metode Pembelajaran Kooperatif Tipe Teams Games Tournament (TGT) dengan Media Teka-teki Silang untuk Meningkatkan Aktivitas Belajar Akuntansi Siswa Kelas X Akuntansi SMK Kristen 2 Klaten Tahun Ajaran 2013/2014". Skripsi. Universitas Negeri Yogyakarta.

Jamil Suprihatiningrum. (2013). Strategi Pembelajaran Teori dan Aplikasi. Yogyakarta: Ar-Ruzz Media.

Kunandar. (2012). Langkah Mudah Penelitian Tindakan Kelas Sebagai Pengembangan Profesi Guru. Jakarta: Rajawali Pers.

Miftahul Huda. (2013). Model-model Pengajaran dan Pembelajaran. Yogyakarta: Pustaka Pelajar Offset.

Moh. Uzer Usman. (2013). Menjadi Guru Profesional. Bandung: PT. Remaja Rosdakarya Offset.

Oxford. (2014). Definition of ludo in Oxford dictionary. Diambil dari: http://www.oxforddictionaries.com/d efinition/english/ludo. pada tanggal 10 November 2014.

Pusat Bahasa. (2008). Kamus Besar Bahasa Indonesia. Jakarta: PT. Gramedia Pustaka Utama.
Sardiman A. M. (2012). Interaksi dan Motivasi Belajar Mengajar. Jakarta: PT. Raja Grafindo Persada.

Siti Mudrikah. (2013). "Implementasi metode Pembelajaran Kooperatif tipe Teams games Tournament (TGT) dengan Permaianan Ular Tangga untuk Meningkatkan Aktivitas dan Hasil Belajar Akuntansi pada Kompetensi Dasar Pembukuan Jurnal Penyesuaian Kelas AK 3 SMK Ma'Arif NU 1 Cilongok Tahun Ajaran 2012/2013". Skripsi. Universitas Negeri Yogyakarta.

Slavin, Robert. (2014). Cooperative Learning Teori, Riset, dan Praktik. (Alih bahasa: Narulita Yusron). Bandung: Nusa Media.

Soni Warsono, Arif Darmawan, dan M. Arsyadi Ridha. (2009). Siklus Akuntansi di Perusahaan Jasa untuk SMA dan MA Kelas XI. Yogyakarta: Asgard Chapter.

Sugiyono. (2012). Metode Penelitian Pendidikan. Bandung: CV. Alfabeta.

Suharsimi Arikunto. (2008). Penelitian Tindakan Kelas. Jakarta: Bumi Aksara.

Suwardjono. (2008). Teori Akuntansi Perekayasaan Pelaporan Keuangan. Yogyakarta: BPFE.

Tukiran Tanireja, Efi Miftah, dan Sri Harmianto. (2012). Model-model Pembelajaran Inovatif. Bandung: Alfabeta.

Wina Sanjaya. (2013). Strategi Pembelajaran Berorientasi Standar Proses Pendidikan. Jakarta: Kencana. 